\title{
УЧЕЊЕТО ЗА БОГОВИТЕ ВО ОНТОЯОГИЈАТА НА НУМЕНИЈ
}

\section{Кратка содржина}

Во текстот се разгледани ставовите на Нумениј за статусот на двата, односно трите бога, во неговиот онтолошки систем. Во релација со изворното ученье за трите бога накратко е споменат проблемот на неговата теориска инклинација кон Истокот, особено кон јудаизмот. Наведени се главните поенти од онтолошката заднина на поставуването и карактеристиките на боговите - со поставуването на Бог и Материјата, претпоставената хиерархизација на божественото според функизите, и статусот на демиургискиот принизип. Заmоа, односот меѓy Првиот Бог и Вториот Бог, и можната поделеност на Првиот, или, поверојатно, Вториот Бог во два бога се разгледани низ соодветните примери од сочуваните фрагменти од делата на Нумениј.

Покажана е дистинкцијата меѓу Првиот Бог, едноставен, самотен и фокусиран на себеси, и Бог кој е поделен на Втор и Трет Бог, односно космосот како производ на Вториот Бог. Идеите за поделеноста на Бог од страна на Материјата се накратко изложени, како и идеите за еквиваленцијата на Врховниот (Првиот) Бог со Доброто, и приманьето на добрината од страна на Демиургот. Разгледани се тврденьта според кои може да се смета дека Првиот Бог, принциипот на постоеньето, владее со (сферата на) битието, а Вториот Бог, пак, со подрачјето на настануването. Поврино се разгледани разлозите за сложеноста на теолошката концепција на Нумениј, и начините според кои конфузијата би можела да биде надмината.

Клучни зборови: НУМЕНИЈ, ПРВ (ВТОР, ТРЕТ) БОГ, ДЕМИУРГ, МАТЕРИЈА, ПОСТОЕЊЕ

Нумениј (од Апамеа), претставник на средниот платонизам, или на неопитагорејството, ${ }^{1}$ ги разгледува раздичните религиозни верувања низ призмата на Платоновата филозофија. Во овој текст ќе биде накратко разгледано теолошкото учење на Нумениј, односно неговата онтолошко-теоиошка концепција за трите бога. ${ }^{2}$ Иако се смета за една од најкарактеристичните концепции за Нумениј, тој изворно му ја припишува на Сократ.

\footnotetext{
1 Постојат и навестувања за негова поврзаност со Халдејските пророштва и со херметичката традиција (Dillon 1996, 94ff; Dodds 1960, 10; Hillar 2012, 183).

2 Употребата на голема буква за „Бог“, „Демиург“, „Прв Бог“, „Втор Бог“, „Трет Бог“, и другите клучни теолошки категории варира кај Нумениј, поради што варира и во овој текст. Наведуватьето оди според принцииот (дело, книга, фрагмент/фрагментот во изданието Numénius, Des Places 1973).
} 
Според Нумениј, Сократ поставил три бога, и раскажувал за нив во стил соодветен за секој посебно. Оние кои го слушале не разбирале што прави, и мислеле дека е неконзистентен, дека зборува во безредие и без план. Платон, кој го следел Питагора, знаел дека точно оттаму Сократ ги зел овие ставови. Тој ги врзувал своите теми на начин кој не бил ниту конвенционален ниту јасен, третирајќи го секој бог онака како што сметал дека треба, криејќи ги своите ставови меѓу јаснотија и опскурност. На таков начин, тој предизвикал причини за несогласување и извртување на неговите учења, што не било поради завист иди здоба, туку поради недоразбраност.

За Нумениј (и ова е важно за неговата сместеност во филозофската традиција), Платон е неопитагореец, како што е и Сократ. По статусот Сократ и Питагора се еквивалентни, со тоа што Платон претставува нивна средина, затоа што ја намалил свеченоста на Питагора за да го очовечи, и ги издигнал итрината и игривоста на Сократ од нивото на иронијата до достоинство и интелектуална тежина. Платон претставува мешавина меѓу Питагора и Сократ, покажувајќи се како подостапен од првиот и подостоинствен од вториот (3а несогласуваната на академичарите со Платон, Fr. 24/1 L).

Се поставува прашањето за тоа каде Нумениј ја пронашол оваа Сократова концепција. Ставовите за трите бога, како и Пиатоновата изјава дека за некои нешта (и тоа нешта од круцијално значење) тој никогаш ништо не напишал, и за нив не постои, ниту ќе постои, расправа (текст) од Платон, туку оние кои сега го носат неговото име припаѓаат на Сократ, се содржат во Платоновото Писмо второ (Ep., II, 314c). Мерлан смета дека Нумениј погрешно претпоставил дека се работи за нов параграф и дека ова „припаѓaат на Сократ" се однесува на сиот претходен дел од писмото, со што, учењето за трите бога станува учење на Сократ (Merlan 1967, 97). Концепциите на Нумениј, ако се претпостави дека се инспирирани од Пиатон, придонесуваат кон дегитимирање на претпоставениот систем од Платоновото ненапишано учење на Тибингенската школа. Сепак, таквиот проблем не е којзнае колку разработен, и секако заслужува засебно истражување.

Проблемот на изворното учење за трите бога кај Нумениј е во релација со уште два проблема: претпочитањето на редигиските концепти за нетелесно божество, и симпатиите што тој ги негувал кон источните учења, особено врската со јудаизмот. Нумениј најавува дека, за да ја постави својата позиција и да ги формира своите заклучоци, ќе се повлече во сведоштвото на Пиатон и ќе го врзе сето тоа со зборовите на Питагора. Така, тој се повикува и на оние кои Платон ги ценел, како него, позајмувајќи ги нивните ритуали и посветувања, односно, што и да е она што браманите и Евреите и маговите и Египјаните организирале (3а доброто, I, 1a, односно 9aL). ${ }^{3}$

\footnotetext{
${ }^{3}$ Нумениј ги вклучува и Евреите во набројувањето на сите народи што го сметале бог за бестелесен, не повлекувајќи се од цитирање на зборовите на пророците во неговите дела, или од давање на (плаузибилни) алегориски толкувања (1b, односно $9 \mathrm{bL})$. Верувањето во бестелесен бог може да се иоцира како разлог за оддавање толкава почит на групите (народите) што ги набројува (Fr. 18/19 L).
} 
Мерлан не смета дека разните референци на Евреите, и особено, Мојсеј, потврдуваат којзнае каква ориентализирачка или јудаизирачка тенденција кај Нумениј. Кај Нумениј нема доказ дека воопшто ја сметал „барбарската“, или посебно еврејската мудрост за супериорна во однос на Платоновата, ниту за нејзин извор или инспирација. Ставот на Нумениј кон Истокот е најдобро да се спореди со тој на Плутарх, кој сакал да се повикува на персиски и египетски религиски концепции, иди со онаа на Диоген Даертиј, тврди Мерлан (Merlan 1967, 99). Во ова Мерлан ја вклучува теоријата на Нумениј за двете космички души (од кои втората е можеби идентична со вториот бог), и, како мошне „негрчка“ теорија, таа за двете души во човека (36L). Познатиот став на Нумениј дека Платон е грчки говоречки Мојсеј во оваа оценка останува проблематичен, и Мерлан е свесен за тоа, и покрај неговото тврдење за недостигот од потврда за приклонетоста на Нумениј кон еврејската мисловна традиција. ${ }^{4}$

Првиот бог, бивајќи на неговото сопствено место, е едноставен, а бивајќи заедно со себе, никогаш не може да биде поделен. Вториот, или Третиот бог, меѓутоа, е еден (IV иди V, 11/20 L). Тој доаѓа во контакт со материјата, која е дијадична, и иако ја унифицира материјата, тој е сепак поделен од неа, затоа што има апетитивен и флуиден карактер (IV или V, 11/20 L). Обрнувајќ́ внимание на материјата, не е посветен на интелигибилното (затоа што во тој случај би бил посветен на самиот себе); обрнувајќи го сето свое внимание на материјата, тој се запоставува себеси. Затоа што се посветил на своето стремење кон материјата, тој доаѓа во контакт со сетилното, го избира и го издигнува сѐ до статус на негов сопствен карактер. Во фр. 11 космосот е претставен како Бог, што го прави единството на Вториот и Третиот бог малку нејасно. Може да се претпостави дека Нумениј не мисли дека космосот е бог во иста смисла како што Првиот и Вториот принцип се богови, туку дека има божествена природа, како творба на Бог, полн со божествено присуство.

Вториот бог е принцип кој на некој начин служи како медијатор меѓу сосема спротивните принципи (Бог и Материјата). Силата која воведува ред во Материјата мора да потекнува од највисокиот Бог, затоа што тој е принципот на редот и добрината. Сепак, таа мора да биде одделена, со што на Бог му се овозможува да остане статичен и непоматен од Материјата, што, пак, го загрозува божественото апсолутно единство. Ова значи дека Бог е истовремено и обединет и поделен. ${ }^{5}$

\footnotetext{
${ }^{4}$ Според Мерлан, на прашањето за тоа кој аспект од Платоновата филозофија Нумениј го имал предвид, за да го спореди Платон со Мојсеј, чесно нагаѓање би бидо дека се работи за начинот на кој Платон, во врска со воведувањето на творецот, ги употребува термините to on аеі на една страна, и библиската формулација „јас сум тој кој сум“ (ehyeh ăšer ehyeh) од друга страна (Merlan 1967, 100).

5 Лангзет забележува дека е интересна намерата на Нумениј да се направат дистинкции во однос на Првиот и на Вториот Бог, преку употребата на diairesis (диајреса), филозофска алатка употребувана од Платон (особено во Државник и Со-
} 
Од нужноста Првиот (бог) да создава, зависи определувањето на статусот на Демиургот - така, доколку не е нужно Првиот да создава (IV или V, 12/21 L), тогаш Првиот Бог треба да се смета за татко на Демиургот. ${ }^{6}$ Нумениј, меѓутоа, сака да го фокусира истражувањето. Така, доколку се работи за „демиургискиот принцип“ и доколку објавиме дека она кое предегзистира би требало да може и директно да создава, тогаш тоа би бил аргументот. Меѓутоа, ако не се работи за Демиургот (создателот) и ако истражувањето води кон Првиот (она кое било прво), таков јазик би бил безбожен, смета Нумениј. Мора прво на еднозначен начин да се согласиме дека Првиот бог не е задолжен за каква било работа (останува неактивен во создавањето), инсистира Нумениј, и дека е Крал. Богот Демиург е главен, кружи низ небесата и владее. Нашето животно патување се одвива поради него, кога Умот се упатува надолу, низ сферите, кон сите оние на кои им е судено да учествуваат во него. Идејата е дека сѐ додека богот гдеда и се врти кон нас, нашите тела живеат и се анимирани од божјото светење со кое се соединуваат. Доколку, пак, Бог се врати во неговата посматрачница, се гасне сѐ освен Умот, кој го продолжува својот живот радувајќи се во благословено постоење (IV или V, 12/21 L). Врската на Првиот бог со создателот (Демиургот), е онаква каква што е положбата на земјоделецот во однос на сејачот. ${ }^{7}$ Оној кој е семето на секоја душа ги спојува сите нешта заедно во нештата кои имаат удел во него; но законодавецот го сади и донесува и внесува во секој од нас она кое било претходно подготвено од страна на Првиот Бог (IV или V, 13/22 L). Раздиката меѓу Првиот и Вториот бог, илустрирана преку земјоделската споредба, е во тоа што Првиот бог е како земјоделецот, го сее семето на секоја душа во соодветната примателка, а Вториот бог е како сејачот, се грижи за семињата, ги кубе, и ги пресадува во индивидуални луѓе.

$\oint u c m)$. Диајреса служи за попрецизно да се дефинира некаква тема преку дисквалификување на небитни членови на поголема група (Langseth 2013, 102 - 103). Во принцип не гледам во други публикации да има спејс вака (меѓу број на стр и тире и тире и број на стр), но искдикав ассерt Нумениј планира некако да го употреби овој метод за да ги дефинира Првиот и Вториот бог за кои претпоставува дека мора да постојат. Дефиницијата до која доаѓa е таа за раздичните нивоа на божеството: определувачки фактор за секој бог е неговиот однос со материјата. Така, Дангзет формулира дека кога „,... филозофот ги прави своите дистинкции во втората половина на фрагментот, дистинкциите што се појавуваат стануваат сфери на активност, а последните редови звучат како божествена драма“ (Langseth 2013, 105).

6 Во ангдискиот превод на Бојс-Стоунс стои „всушност, она што е прво (првиот принцип, иди првиот бог) не треба да создава. Така, првиот бог мора да се смета за татко на богот создател“ (Numenius, Boys-Stones 2014, 6).

7 Де Плас забележува дека раздиката меѓу земјоделецот и сејачот е веројатно замислена како односот меѓу земјопоседник и работник кој за него работи (Des Places, ad fr. 9). 
Додс тврди дека ова е сигурно базирано на Тимај 41c-d, но дека функцијата на Демиургот на Платон е овде конфузно пренесена на Првиот бог, а функцијата на Помалите богови, на вториот Бог. Дел од опскурноста се должи на уништениот превод - излегува дека Нумениј кажува дека Првиот бог е семето на душата што го сади, што е неточно (Dodds 1960, 15). 8 Во преживеаните делови од опусот на Нумениј нема ништо што би упатило на тоа дека Првиот (бог) треба да денотира и Битие и Примарност. Како еден од закдучоците во расправата со предлозите на Додс за разбирање на Првиот принцип, Витакер смета дека доколку не се најде соодветно оправдување на овој предлог на Додс, нема раздог „првиот“ воопшто да стои во фр. 13 (Whittaker 1978, 150). Витакер, следејќи го Фестижиер, мисли дека Нумениј го имал на ум делот од 2. Мој., 3,14, и го лоцира Филон како најлогична врска меѓу старозаветниот извор и Нумениј (Whittaker 1967, 196). Тарант смета дека Витакер е несомнено во право кога претпоставува дека Нумениј бил запознаен со јудео-христијанскиот начин за реферирање на Бог како „оној кој е“, особено што и други филозофи од неговото време, помалку засегнати од грчката религија, имале учења во кои биле вклучени слични формули. Што се однесува до предложената поправка на преводот на фр. 13, Тарант не смета дека не е потребна, но мошне потежок проблем гледа во помирувањето на овој фрагмент во релација со Тимај 41a ff (Tarrant 1983, 19-20). ${ }^{9}$

Првиот бог е фиксен, недвижечки, додека вториот е во движење. Првиот се посветува на интедигибилни објекти, а Вториот на интелигибилни и сетилни објекти, тврди Нумениј. Движењето му припаѓа на Вториот бог, а природното движење на Првиот бог е мирувањето. Од него низ вселената се издева редот на светот, како и неговите трајност, стабилност и безбедност (IV или V, 15/25 L).

Во божествената хиерархија на Нумениј, значи, има дистинкција меѓ Првиот бог, едноставен и фокусиран само на себеси, и бог кој е Втор и Трет. Вториот и Третиот се еден бог, но може да се сметаат и како одделни. Поентата е дека кога Бог е поврзан со материјата, тој е поделен и растргнат од материјата. Демиургот не е гностичкиот незнаечки Демиург, туку како Демиургот од Тимај, иако раздикувањето меѓу врховен бог и бог создател е гностичка идеја. ${ }^{10}$ На бог од Тимај не му пречи неговото совр-

\footnotetext{
8 Во врска со тоа дали „Првиот“ се однесува на Прво Битие/Прв Бог, а во рамки на нападот на Витакер на предложеното решение за превод и толкување на фр. 13 на Додс види Whittaker 1967, 196, и Whittaker 1978, 144 - 154.

${ }^{9}$ Нема проблем во фактот што Нумениј го нарекува Првиот Бог „оној кој е“, барем не повеќе отколку фактот што Вториот Бог го нарекува „законодавач“, но Тарант смета дека прашањето е во врска со тоа зошто Нумениј би ги одбрал овие описи во контекст на фр. 13, особено што воопшто не ја разјаснуваат предложената аналогиja (Tarrant 1983, 23).

10 Дилон насетува проблем во ставот на Нумениј дека демиургот создава како резултат на orexis за материја (желба, апетит, чезнеење), употребувајќи го зборот чез-
} 
шенство, напротив, сака да го сподели и да го воведе во нередот, тоа е во неговата природа. Системот на Нумениј не дозволува ова да биде финално решение. Демиургот опишан во Тимај не е определен како неподвижен и статичен на ист начин како битието кај Нумениј.

Ако Демиургот (создателот на настанувањето) е добар, Демиургот во однос на суштината ќе биде самото Добро, со иста природа како суштината. Вториот (бог), со тоа што е двоен, е лично одговорен и за произведување на самата Идеја, и за светот - од една страна е создател, а од друга страна е потполно посветен на контемплацијата. Потем Нумениј ги набројува четирите ентитета: Првиот бог, самото Добро; неговиот „подражавач“, создателот (Демиургот), кој е добар; супстанцијата (суштината), и тоа една од Првиот (бог), една од Вториот (бог); и нејзината копија, односно убавиот космос, разубавен преку неговото учество во Убавото (За Доброто, $\mathrm{V}, 16 / 25 \mathrm{~L})$.

Нумениј објаснува како Платон сфатил дека само Демиургот бил признаен од луѓето, а првиот Ум, Самото битие, бил потполно непрепознаен од нив. Затоа, како Платон да сакал да каже дека Умот за кој луѓето мислат дека е прв, всушност не е, туку има уште еден Ум кој му претходи, древен и божествен, појаснува Нумениј (VI, 17/26 L).

Онтолошката конструкција Нумениј ја илустрира на следниов начин. Морепловец седи високо на својот кораб во морето и кормилари, пишува Нумениј, но очите и умот му се насочени кон небото, така што, што се однесува до него, неговата патека следи насоки од небесата над него, иако плови по морето под него. Имајќи ја врзано материјата заедно во хармонија, така што таа не може да падне или да се измолкне, Демиургот седи над неа, како коработ на морето. Тој ја насочуваа хармонијата, и наместо кон небесата, гледа кон Бог над него кој му го привлекува погледот, и од ваквата контемплација ја добива својата моќ на судење, а еланот - од неговиот копнеж (VI, 18/27 L). Нумениј објаснува дека телата ги разбираме преку индукција од ним слични нешта, и од дистинктните знаци споделени од нешта кои се во јукстапозиција. Поентата е дека нема начин да се разбере Доброто од нешто што му е јукстапозиционирано, или пак, од некое перципирливо нешто кое му е слично, туку потребен е инаков пристап. Мора да се повлечеме далеку од објектите, за да може перцепцијата

неень, lust (Dillon 1996, 369). Кај Де Плас е желба, désir. Керабин мисли дека желба (во смисла на стремечка желба) е поблиску до значењето кај Нумениј (Carabine 1995, 96). Токму затоа што во гностицизмот се верува дека демиургот создава без да знае за идеите, Де Фогел смета дека не треба Вториот бог на Нумениј да се изедначува со гностичката концепција за демиургот (De Vogel 1964, 25). Покрај оваа, постои и опцијата дека изворот на оваа идеја кај Нумениј не е гностицизмот, туку Филон (Leg., III, 207).

Во врска со можноста да се сфати дистинкцијата меѓу Вториот и Третиот бог како дистинкција меѓу трансцендентните и иманентните аспекти на демиургот, види Puech 1934, 756. 
да се припои со Доброто, кое е само, и кое е неискаждива, потполно неопислива божествена самотија (I, 2/11 L).

Во врска со идејата за супериорноста на Отецот над битието и умот, Дилон се осврнува на сопствениот заклучок од делото Средните платонисти и забележува дека Нумениј се колебал околу идејата, воден од поставувањето на Втор бог кој треба да се изедначи со Вистинското битие и Умот, но не се одважил да го тврди ова. Дилон смета дека традиционалната поврзаност во грчката филозофска традиција со концептот за Бог кој е во пол-

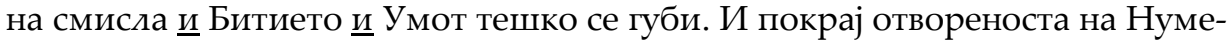
ниј кон вдијанија од источните религии, се чини дека не бил подготвен да го напушти овој концепт. Сепак, Нумениј дошол блиску до напуштање на концепцијата, тврди Дилон. Така, кога ја дава сликата за фрлање поглед кон Доброто, како гледањето на чамец кој скока по брановите, го објаснува неговото подрачје како апсолутна неискажлива и неопислива самотија, а Доброто како нешто кое стои на Битието. Ваквата формулација внимателно балансира меѓу идејата дека нешто е супериорно на, или отаде Битието, и највисокото ниво на Битието (Dillon 2007, 398). Може да се тврди дека за Нумениј, Доброто е на некој начин отаде Битието. Од друга страна, пак, забележува Дилон, фрагментот завршува со формулација на врвниот објект на нашата потрага - постоењето ti esti to on, што потврдува дека Нумениј не го поставил Доброто како супериорно и отаде Битието (Ibid.).

Нештата кои учествуваат во Доброто не учествуваат во ништо друго, освен мислата. На ваков (и ниеден друг) начин може да се здобие со предноста на спојување со него. Што се однесува до мислата, таа оди само со Првиот (бог). Платон преку силогизам покажал дека Доброто е едно, објаснува Нумениј. Тоа е затоа што, ако Вториот (бог) е добар, не поради самиот себе, туку преку изведување од Првиот, очигледно е дека она во кое учествува за да биде добар е самото добро, ${ }^{11}$ особено што Вториот учествува во него како во Доброто (19/28 L).

Пишувајќи за Демиургот на прозаичен и секојдневен начин во $\mathrm{Tu}$ мај, Платон определил дека „тој бил добар“ (29е), а Доброто во Држава го нареко „Идејата на Доброто“ (508е), забележува Нумениј. Така, доброто е идеја на создателот, кој се појавува како добар кон нас учествувајќи во првото и единствено [добро]. Затоа, Нумениј смета дека ако создателот е добар преку учеството во Првото Добро, тогаш првиот Ум, како самото Добро, би бил неговата Идеја (20/29 L).

Нумениј го нарекува Првиот Бог татко, Вториот создател, и Третиот Бог дело, артефакт, затоа што тоа е космосот. Според него, создателот е двоен, Првиот бог и Вториот бог, додека она што е создадено е Третиот, односно врската ја следи схемата предок-директен потомок (син)-инди-

11 Тука може да се забележи двојното значење: и самото е добро, и истовремено е самото Добро. 
ректен потомок (внук). ${ }^{12}$ Прокло (според кого го имаме овој фрагмент), смета дека Нумениј греши во вбројувањето на Доброто во овие причини, затоа што тоа не треба да се поврзува со други нешта, иди да биде второстепено во однос на што било друго (21/24 L). ${ }^{13}$ Ова е извештајот за учењето на Нумениј од страна на Прокло во Коментарите на Тимај, и може да се смета за претерана симплификација. Според Прокло, Нумениј издожува три бога, нарекувајќи го првиот Отец, вториот Создател (poietes), и третиот Создадено (роiema), затоа што космосот е според него третиот бог. Според неговата теорија, создателот (demiourgos) е двоен - составен од Првиот Бог и од Вториот, додека третиот бог е креацијата (to dedemiourgemenon). Прокло ги претпочита овие називи, наместо „да ја употребува неговата помпезна терминологија - дедо, син и внук" (21/24 L). Дилон не гледа раздог да се сомневаме дека Нумениј навистина ја користел оваа терминологија, но смета дека Прокло греши во две поенти во ова резиме. Од фрагментите се разбира дека "создателот“ не се Првиот и Вториот бог, туку Вториот и Третиот бог, и, по истата динија, Третиот бог не треба да биде одделен од Вториот, туку сметан како негов понизок аспект. Прокло бил и делумно во право во толкувањето на Нумениј: постои степен на интеракција меѓу трите бога кај Нумениј (Dillon 2007, 400). ${ }^{14}$ Се чини дека Прокдо дуплира погрешен бог - тврди дека Демиургот е Првиот и Вториот Бог заедно, иако Нумениј самиот кажува дека Демиургот е Вториот Бог (фр. 12, на пример), со што мисли на Вториот и на Третиот Бог заедно (двата бога кои се еден). ${ }^{15}$

12 Очигледна е инспирацијата од Херметичкиот кориус, или можеби од некаков заеднички извор: Од Еден Извор сите нешта зависат, додека Изворот зависи од Едното и само од Едното. Изворот е придвижен да стане повторно извор, додека Едното/Едниот е вечно во мирување и непридвижуван(о) (CH, X, 14). Тие се три: Бог, Отецот и Доброто; космосот; и човекот. Бог го содржи космосот, космосот го содржи човекот. Космосот е секогаш Син Божји, а човекот како да е дете на Космосот (Ibid). Види уште и CH, VIII, 1; VIII, 2; VIII, 5.

${ }_{13}$ Во фр. 16 Нумениј објаснува дека првиот Бог е наречен nous, тој е Доброто по себе и принципот на постоењето, односно тој е Демиургот на битието, според што Вториот бог е принципот на настанувањето. Во фр. 21, пак, стои дека Првиот и Вториот бог е двоен, а не Вториот и Третиот. Во фр. 22 е повторена идејата за тесна врска меѓу Првиот и Вториот бог. Така, Првиот е она кое навистина е, поврзано со Вториот бог преку nous, и со Третиот преку дискурзивното размислување. Прокло го темели ваквото поврзување на Првиот и Вториот бог врз ставот на Нумениј дека Првиот бог е Демиургот на битието.

${ }_{14}$ Разбирањето на концепцијата на трите бога е усложнето и од описот на Трите бога од страна на Прокло (фр. 21), во кое, според Прокло, Нумениј го употребува „таткото и создателот“ од Тимај како да реферира на два одделни бога, иако во зборовите на Тимај се реферира на истиот демиург (Dillon 1971, 143 - 144).

${ }^{15}$ Види го овој став кај Merlan 1962, 140; Dillon 1996, 367.

Дори сфаќа дека Прокдо греши, но за грешката го обвинува недоводно строгото раздикување на Нумениј на највисокиот принцип од материјалниот свет (Dörrie 
Во врска со првите принципи, Нумениј ја отфрла стоичката теорија во корист на учењето на Питагора со кое, како што вели, се согласувал Платон. Питагора го нарекувал бог „едност“ (монада), а материјата „двојност“ или „двојство“ (дијада), и тврдел дека бесконечното двојство не е создадено, но дека ограниченото двојство е создадено. Идејата е дека двојноста нема потекло или создавање пред да биде украсена, пред да добие форма и ред, а се создава кога ќе биде украсена и разубавена од бог, дејствителот на редот. Создавањето се случува доцна, и затоа неуредената и несоздадена двојност треба да се мисли како истодобна со бог, кој ја довел во ред. Но, некои питагорејци не го разбирале точно ова тврдење, туку сметале дека Питагора мислел дека неопределената и немерена двојност произлегла од едноста, која само се преправила во двојност, уназадувајќи ја својата природа. Ова не е точно, затоа што едноста, според него, престанува да биде тоа што била, и потпостои како нешто што не е, односно двојност (ова важи за претворањето на бог во материја и на едноста во широка и неопределена двојност), и никој со барем малку образование не треба да го прифати, тврди Нумениј. Покрај ова, тој потсетува дека стоиците сметаат дека материјата е конечна и ограничена од својата природа, а Питагора - дека таа е бесконечна и неограничена. Стоиците расправаат дека нешто чија природа е да биде немерливо не може да биде ставено во граници и во ред. Питагора, пак, тврди дека едно нешто, бог, ги има способноста и моќта да го стори тоа. Она што природата не може да го постигне, бог лесно може, затоа што е помоќен од која бидо способност, односно, тој е самиот извор на сите способности на природата (52/30 L, CCXCV). Питагора мисли дека материјата е во флукс и без квалитети, иако не во стоичката смисла на посредничка природа меѓу доброто и здото, затоа што според него е мошне очигледно штетна, резимира Нумениј. Питагора (како и Платон, впрочем), смета дека бог е принципот и причината на она што е добро, а материјата - на она што е зло. Производот на формата и материјата е индиферентен (како посредничката природа кај стоиците), но тоа не е материјата, туку космосот како мешавина на добрината на идејата и на злото на материјата. Поради ова, смета Нумениј, старите теолози мислеле дека светот се раѓa од провидение и нужност (52/30 L, CCXCVI). Нумениј објаснува дека според Платон, на светот му се доделени добрите нешта преку татковски бог, а лошите нешта се држат за него преку здото на материјата. Ако бог ја поправил материјата, која се карактеризира со нетрпеливост, импулсивност и слично, и вовел ред во нејзината хаотична вознемиреност (како што стои во Тимај), тогаш мора да се претпостави дека нејзината збунета дрскост доаѓ од некаква хазардна случајност, а не од заштитните планови на провиданието. Душата на материјата не е без супстанција, смета Питагора, туку му се спротивставува на провидението,

1970, 222). Ова е исто така неточно, ако се земе предвид дека во кн. I-III од За Доброто, има точно такво строго раздикување. 
трудејќи се да пркоси на неговите планови преку силите на нејзината злоботија (Тодоровска 2018, 193).

Според Нумениј спознатлив е само Демиургот, додека Првиот бог (првиот nous, Убавината по себе), е сосем неспознатлив. Можно е Нумениј да говори во гностички рамки, но мошне поверојатно е дека реферира на Платон, имајќи го разбрано во смисла дека постои татко и постои создател, за да ја формира позицијата за неспознатливоста. Умот (nous) што човековиот интелект (едвај) го перципира не е Првиот бог, затоа што пред него постои друг ум, уште побожествен. Ова упатува на мислењето дека Бог е над nous, што, пак, заедно со реферирањето на Првиот бог како поus, воведува додатна конфузија во однос на статусот на божествената хиерархија, особено што во фр. 16 Првиот бог не е претставен како мислечки интелект, затоа што за да мисли има потреба од Вториот бог. Првиот бог останува на ниво на битието и nous.

Врховниот бог е „идејата на Доброто (од, Држава 508Е), со тоа што Првиот бог е идејата од која Демиургот ја прима својата добрина. И покрај неколку назнаки што укажуваат на тоа дека намерата на Нумениј можеби била да воведе трансцендентен принцип (во смисла на тоа дека е отаде постоењето и умот), нема зачувани фрагменти во кои има обиди за експлицитно формулирање на ваквата концепција.

Врховниот бог, кој е вечно присутен, може уште да биде сметан за Доброто (односно Добрина; tagathon), прва интелигенција, бестелесност, Она кое е, или битието. Првиот бог може да се смета за Идеја во Платоновска смисла, и така да служи како парадигма за Вториот бог, кој, пак, може да се смета за втора интелигенција, односно за создател, и кој е добар затоа што учествува во добрината. Понатаму, како што беше споменато, може да се смета дека има Трет бог - светот како производ на Вториот бог. Односно, може Вториот бог да се смета за двоен - делумно посветен на контемплирање на Првиот бог (или интелигибилното), делумно на создавање, и, според Идеите како водилки, на одржување на видливиот космос. Во оваа последна функција тој се наоѓ во опасност од посветување премногу внимание на материјата од која го создава космосот.

Првиот бог нема потреба да прави што било, нема работа, според што космосот не е негово дело, туку е дело на Вториот бог, создателот. Првиот бог владее со подрачјето на битието, тој е принципот на постоењето, а Вториот владее со подрачјето на раѓањето. Првиот Бог е принцип на соединување, спротивен на Материјата (иди дијадата). Бог е статичен и неподелен („Доброто е едно“, фр. 19). Тој е она кое постои, битието (во кн. II претставено како ноетичко).

Вториот Бог си ги врши своите ноетички дејства меѓу Првиот и Третиот Бог. Вториот бог е принцип кој е ноетички, но поделен, составен од неколку ноетички објекти. Тој ги содржи Идеите, значи е нешто како бо- 
жествен Ум. ${ }^{16}$ Третиот Бог, резултат на заборавањето на Вториот бог на себе и грижењето за Материјата, е активниот принцип. Тој ја организира Материјата според ноетичките модели што ги дава Вториот Бог. Според О’Браен, може да се направи еквиваденција меѓу битието и Првиот бог, ако се следи фр. 17. Ова, сепак, не е беспоговорно, затоа што се чини дека Нумениј има проблем со идејата дека неговиот Прв бог е отаде битието (јава врз битието - фр. 2). О’Браен тврди дека Нумениј е речиси принуден на ваквата позиција, затоа што неговиот Втор бог е изедначен со вистинското постоење (битието) и Умот, а сепак не скршнува од традиционалната грчка идентификација на Бог со Битието и со Умот (O’Brien 2015, 142).

Третиот бог создава така што применува врз Материјата унифицирачко дејство, во што наликува на Демиургот од Тимај. Платоновиот Демиург создава гдедајќ́ во Идеите, кои, во системот на Нумениј, се мисли во умот на Вториот Бог. Фреде ја смета за контроверзна оваа интерпретација за идентитетот на трите бога (Frede 1987, 1054 -1055). Сепак, фактот дека Нумениј говори за два бога, односно за три бога, иесно може да се разреши преку неговиот став од фр. 11 дека Вториот и Третиот бог се еден. Кај Фреде не се забележува разбирање (Frede 1987, 1056-1058) дека „Вториот Бог“ е или божествениот Ум (вториот од три бога), или, пак, двата бога кои се еден (вториот од два бога). Керабин не смета дека Нумениј го гледал Првиот бог како демиург на светот, туку едноставно како извор на постоењето. Нејзе ѝ пречи некомпатибилноста на разбирањето на бог како демиург со другите фрагменти, која би се одбегнала кога формулацијата би била „принцип на битието/постоењето“ (Carabine 1995, 98). Организирајќи ја Материјата, и создавајќи со неа, Третиот Бог создава онтолошки слоеви меѓу него и Материјата. ${ }^{17}$

Тријадичната поделба на божеството на Нумениј истовремено е и не е сложена. Така, едноставно може да се разбере дека ова се Трите Бога, кои произдегуваат од (дискусијата за) Двата Бога, поради тоа што контактот со Материјата го поделува Вториот Бог во две функции, што се сметаат за раздични богови. Од друга страна, тешкотијата се состои во разгледува-

\footnotetext{
16 Види ги ставовите кај Rist 1962, 179; Dillon 1992, 100; Langseth 2013, 108 - 109. Според Хилар, во питагорејско-платонистичката религиозна традиција Нумениј го вовел Вториот трансцендентален (sic!) и ноетички ентитет меѓу врховното суштество и вселената. Несомнено под вдијание на изјавата на Платон за трите принципа на вселената, го извел концептот на трите Бога, раздикувајќи ги сите нешта според нивниот статус и ред (Hillar 2012, 183 - 186).

17 Резимето на Мартано се повикува на изјавата на Прокло дека Третиот бог е космосот, што не е точно ако се чита фр. 11 - Третиот Бог го допира сетилното подрачје и го издигнува до неговиот сопствен карактер - го создава светот (Martano 1960, 40). Затоа, ги наведува нивоата на метафизичката/теолошка схема на Нумениј, редејќи ги како 1. Доброто, 2. Демиургот кој мисли и дејствува, 3. Светот, 4. Непостоечкото (односно Материјата) (Ibid., 47) - Третиот Бог и овде му е еквивалентен со светот, а не со Деимургот кој создава.
} 
њето на Вториот и на Третиот Бог понекогаш како одделни, а понекогаш како раздични функции на еден (Вториот) Бог. Постојат и формулации во кои Вториот бог не е поделен во Втор и Трет бог, туку е еден Бог кој и мисли и дејствува. Проблем е и што „амалгамскиот“ Втор бог има создавачки аспект (кого, впрочем, го добива од Третиот), и затоа Нумениј го наведува како Демиург (фр. 12 и 16, на пример), иако демиургиската функција е попрецизно исподнувана од Третиот Бог, создателот. Сепак, од контекстот може да се разбере за кој бог Нумениј зборува кога реферира на „Вториот" бог. ${ }^{18}$ Вториот Бог (двата бога кои се еден) е така составен поради неговиот контакт со Материјата. Врховниот Бог останува сосем недопрен од какво било вдијание на Материјата, во неговото сопствено подрачје, а понискиот бог се произведува преку искусувањето на поделбата од Материјата на два начина - преку одделувањето од Првиот Бог, и внатрешното поделување во Втор Бог (божествениот ум) и Трет Бог (создателот).

Во корисна табела во која ги споредува основните онтолошко-теоиошки категории кај св. Јустин Маченик со концепциите на Нумениј, Хилар го резимира следново. Првиот Бог е татко на Вториот Бог, прост и неделив, Доброто (-во-себе), извор и принцип на постоењето, непроменлив. Тој не создава директно, посветен е на интелигибилното, тој е во финална анадиза на причината на сето. Од него доаѓаат редот и вечноста на светот. Со Вториот Бог е поврзан како земјоделецот со сејачот; поврзан е со сето она што е живо како негов принцип. Вториот Бог дејствува како создател, Демиург, посветен и на интелигибилното и на сетилното подрачје. Од желба за третиот Бог тој создава. Кога е свртен кон нас, телата се анимираат од неговите зраци. Вториот Бог е законодавач, го пресадува и распоредува она што е всадено од над него, од Првиот Бог. Вториот Бог е добар преку учество во Доброто на Првиот. Вториот Бог е слика и имитација на Првиот. Третиот Бог како свет е произведен од Вториот, како ум е поврзан со човековото дискурзивно мислење. Врската меѓу Првиот и Вториот е како на оган запален од друг оган, како меѓу земјоделец и сејач, дарител и примател. Врската е како меѓу Татко-создател и создаденото. Хилар ја наведува и татко-син-внук врската, но не елаборира во ова кратко резиме (Hillar, 2012, 184 - 186).

Ритер и Прелер го користат „поделувањето“ на Вториот бог во Втор и Трет бог како оправдување за нивната теорија дека Вториот бог е Добрата космичка душа, а Третиот бог е Злата космичка душа (Ritter, Preller 1898, 516 apud J. L. Langseth 2013, 108, non vidi). Дангзет смета дека Нумениј би се ужаснал од оваа замисла (ibid). О’Браен забележува дека Демиургот се чини свртен во две насоки за време на чинот на космогонија: ги контемплира Идеите, и го пренесува Интелигибилното на сетилното под-

18 Лангзет предлага раздика со употребата на определен член - реферира на Вториот од Трите Бога како „Втор Бог“ (the “Second God”), божествениот Ум, а на Вториот од Двата Бога како „Вториот бог“ („The Second God”), Langseth 2013, 109. 
рачје. Дел од проблемот се состои во прашањето за тоа зошто Демиургот треба да биде поделен на две преку Дијадата. О’Браен не мисли дека е случај во кој горниот (односно, нагоре-свртениот дел) од божеството се враќа на тоа да ги контемпдира Идеите, а долниот дел се посветува на постојано создавање на сетилниот свет. Можно е Третиот бог да е само понизок аспект од Вториот. Очигледно Демиургот создава како резултат на копнеж, што не е којзнае колку вредно за пофалба, затоа што го спречува да го контемплира интелигибилното подрачје, и прави да ја заборави сопствената природа. Овој „грешен елемент“ може да се смета како да е исфрлен од Вториот Бог, слично на набркувањето на Софија од Пиерома во гностичките системи. Сепак, О’Браен не мисли дека е неопходно да се постави понизок аспект од Вториот бог - копнежот на Демиургот може да се гледа во поблагонаклонето светло, како дел од природната желба да создава (за која може да се смета дека е и раздогот зошто Првиот бог го произведува Вториот бог). Можно е, додава О’Браен, дека Првиот Бог едноставно подедил предпостоечки ентитет во Вториот и Третиот бог, кои понатаму ја делат функцијата на Демиургот. Ова, меѓутоа, произведува тешкотии во објаснувањето на дедо-татко-внук терминологијата кај Прокло, и прави проблем со фр. 12 (O’Brien 2015, 145).

Несомнено, во хиерархијата на Трите бога постои извесна конфузија, која можеби се должи на скромноста на зачуваните извори. Сепак, огромен дел од концепциите на Нумениј се јасно раздожени и сочинуваат сложена и предизвикувачка теолошка и онтолошка поставеност. Теологијата на Нумениј е извонредно важна како засебно подрачје, за изучувањата на системите од платонистичката традиција, и за развојот на античките концепти за Демиургот.

\section{Питература:}

CARABINe, D. (1995). The Unknown God. Louvain: Peeters Press.

De Vogel, C. J. (1964). Greek Philosophy, vol 3. Leiden: Brill.

Dillon, J. (1971). "Harpocration's 'Commentary on Plato: Fragments of a Middle Platonic Commentary." California Studies in Classical Antiquity 4, 127, n. 4: 125-146.

Dillon, J. (1996). The Middle Platonists - 80 B.C. to A.D. 220, Ithaca: Cornell University Press.

Dillon, J. (2007). „Numenius: Some Ontological Questions.“ Bulletin of the Institute of Classical Studies, Supplement No. 94, Greek \& Roman Philosophy 100 Bc - 200 ad: Volume II, pp. 397-402.

Dillon, J. (1992). "Pleroma and Noetic Cosmos: A Comparative Study." In J. T. Wallis, J. Bregman, Eds. Neoplatonism and Gnosticism. Albany: State University of New York, pp. 99-110. 
DodDS, E. R. (1960). “Numenius and Ammonius". Les Sources de Plotin. Entretiens Fondation Hardt 5, Genève: Vandoeuvres, pp. 3-32.

DÖRRIE, H. (1970). “Der König: Ein Platonisches Schlüsselwort.” Révue Internationale de Philosophie 24: 217-235.

FREDE, M. (1987). “Numenius." ANRW 2.36.2: 1054-1055.

HILlar, M. (2012). From Logos to Trinity - The Evolution of Religious Beliefs from Pythagoras to Tertullian. Cambridge: Cambridge University Press.

LANGSETH, J. L. (2013). Knowing God: a study of the argument of Numenius of Apameia's On the good, PhD thesis, University of Iowa.

Martano, G. (1960). Numenio d'Apameo: Un Precursore del Neo-Platonismo. Napoli: Casa editrice Armani.

MEAD, G. R. S. (1906). Corpus Hermeticum, vol. II, Theosophical Publishing Society, 1906, <http://gnosis.org/library/grs-mead/TGH-v2/th221.html> (15.05.2020).

Merlan, P. (1962). “Drei Anmerkungen zu Numenius.” Philologus 106: 137-145.

Merlan, P. (1967). "Greek Philosophy from Plato to Plotinus." In A. H. Armstrong, Ed., The Cambridge History of Late Greek and Early Medieval Philosophy. Cambridge: Cambridge University Press, pp. 14-135.

NumÉnIUS (1973). Fragments. E. Des Places, trans.\&ed. 'Budé' édition. Paris: Belles Lettres.

NumENiUs (2014). Numenius' fragments, draft translation, based on the 1972 'Budé' edition by E. des Places, Numénius, Fragments, Belles Lettres, Paris, G. BoysStones, trans. Durham University.

O'BrIEN, C. S. (2015). The Demiurge in Ancient Thought, Cambridge: Cambridge University Press.

Philo Of AleXANDria (1993). The Works of Philo, Complete and Unabridged, C. D. Yonge, trans.\&ed. Peabody: Hendrickson.

Plato (1997). Complete Works. J. M. Cooper, trans.\&ed. Indianapolis: Hackett Publishing Company.

PuECH, H-Ch. (1934). „Numénius d'Apamée et les théologies orientales au second siècle."Aiphos, 2: 745-778.

RIsT, J. M. (1962). “Theos and the One in Some Texts of Plotinus." Medieval Studies, 24: 169-180.

Ritter, H, Preller, L. (1898). Historia Philosophiae Graecae, Gotha: Friedrich Andreas Perthes.

TARrant, H. (1983). "Numenius' fr. 13 and Plato's Timaeus." Antichthon 13: 19-29.

ТОдОРОвСКА, М. (2018). „Одредени аспекти од онтолошките системи на Апулеј и на Нумениј." Филозофска трибина 41, бр. 22-23: 175-195.

WhitTaker, J. (1967). “Moses Atticizing.” Phoenix, 21: 196-201.

WhitTaker, J. (1978). "Numenius and Alcinous on the First Principle." Phoenix, Vol. 32, No. 2: 144-154. 